\title{
Effects of Mineral Fertilizer Doses and Ratios on Tea Yield and Quality
}

\section{Tran Xuan Hoang ${ }^{1}$, Vu Ngoc Thang ${ }^{2}$, Dang Van Thu ${ }^{3}$, Nguyen Ngoc Binh ${ }^{1}$, Nguyen Van Toan ${ }^{3} \&$ Dinh Thai Hoang ${ }^{2}$}

${ }^{1}$ Tea Research and Development Center, Northern Mountainous Agriculture and Forestry Science Institute, Phu Tho 293823, Vietnam

${ }^{2}$ Faculty of Agronomy, Vietnam National University of Agriculture, Hanoi 131000 ,

Vietnam

${ }^{3}$ Northern Mountainous Agriculture and Forestry Science Institute, Phu Tho 293823, Vietnam

\begin{abstract}
Mineral nutrients are essential to plant growth and development. The present study aimed to evaluate the effects of mineral fertilizer doses and $\mathrm{N}: \mathrm{P}: \mathrm{K}$ ratio on growth, yield, and raw material quality of the tea variety $\mathrm{PH} 10$ to improve the production of high-quality tea products. The field experiment was conducted from 2015 to 2017. A two-factor experiment was designed by split-plot design with three replications. The mainplot treatments were three fertilizer doses of $\mathrm{N}$ for one metric ton of fresh shoot products $\left(30,40\right.$, and $\left.50 \mathrm{~kg} \mathrm{~N}^{-1}\right)$. The subplot treatments were two NPK ratios $(3: 1: 1$ and $3: 1: 2)$. Plant height, leaf canopy, plant diameter, shoot yield parameters, shoot components, biochemical compounds, and sensory quality for Oolong and Sencha tea products were evaluated. The results showed that increasing fertilizer doses from 30 up to $40 \mathrm{~kg} \mathrm{~N}$ per ton of fresh product improved remarkably growth, yield, and tea quality of PH10 variety. Different fertilizer ratios resulted in variations in plant growth, the content of carbohydrate, sensory quality for taste and flavor as well as total sensory quality with higher values at NPK ratio of 3:1:2. Applying mineral fertilizer with an NPK ratio of 3:1:2 and $40 \mathrm{~kg} \mathrm{~N}$ per ton of fresh shoot products was recommended to bring about the most benefits of tea yield and quality as well as economic profit.
\end{abstract}

\section{Keywords}

Oolong tea, Sencha tea, mineral fertilizer, yield, quality

\section{Introduction}

Tea (Camellia sinensis L. O Kuntze.) is an important cash crop.

Received: October 27,2020 Accepted: March 13, 2021

Correspondence to vungocthang@vnua.edu.vn; dthoang@vnua.edu.vn

https://vjas.vnua.edu.vn/ Nowadays, tea is grown in 48 countries with a total area of around 4.2 million hectares and total production of 6.34 million tons (FAOSTAT, 2018). Vietnam is one among five world tea producers and ten world tea-exporters. In 2019, Vietnam exported 
137,000 tons at a value of USD 236 million (VITIC, 2020).

Although being a world tea producer and exporter, the export value of Vietnam tea products is still not high. The main reason is that the most product was in the form of raw material and poor competition of made tea products. To improve the quality of tea products, the processing techniques have been improved to satisfy the material requirement of high tea products such as green tea, Oolong, Longjing, or Sencha teas. Moreover, several introduced tea varieties such as Thuy Ngoc, Phuc Van Tien, or Kim Tuyen have been tested and released. Among these varieties, $\mathrm{PH} 10$ is a high yielding and highly tolerant to common pests and diseases, and has high raw material quality for producing Oolong and Longjing teas. However, to exploit the potential of tea production, the adoption of suitable cultivation techniques is necessary.

Being a perennial plant with high productivity, tea consumes annually a large amount of nutrients. The production of 1-ton tea required $8.8-12.2 \mathrm{~kg}$ nitrogen $(\mathrm{N}), 1.0-1.2 \mathrm{~kg}$ phosphorus $(\mathrm{P})$, and $3.2-3.9 \mathrm{~kg}$ potassium $(\mathrm{K})$ (Tang et al., 2020). Therefore, fertilizer supplements to return mineral nutrients need to be practiced frequently. Owuor (2001) reviewed that the use of fertilizers in tea production was widely practiced in tea production to improve tea productivity. Hajiboland (2017) also insisted that fertilizer was a common agricultural practice for higher production and increased tea quality. However, the abuse of chemical fertilizer did not improve soil fertility but harmed the soil bacterial community (Qiu et al., 2014). Barbora (1991) reported that high $\mathrm{N}$ rates had harmful effects on the tea bush and its productivity. Furthermore, the redundancy of chemical fertilizer raises waste and environmental pollution as well as reduces economic efficiency. The previous studies suggest that mineral compounds be combined to improve tea yield and quality. Better yield responses were obtained with higher amounts of $\mathrm{P}$ and $\mathrm{K}$ compound nitrogenous fertilizers (Clowes, 1986). A combination of $\mathrm{P}$ and $\mathrm{K}$ was shown to be beneficial to quality (Willson \& Choudhury, 1968). Venkatesan \& Ganapathy
(2004) reported that tea quality was impaired when either $\mathrm{N}$ or $\mathrm{K}$ was used at high levels, but the impairment was reduced when these two minerals were combined at a ratio of 1:0.83. However, because of the different responses of tea varieties to fertilizer application (Amali et al., 2019), the optimal mineral dose, as well as ratio, may be different for each tea variety. The objectives of this study were to evaluate the growth, yield, and raw material quality of tea variety $\mathrm{PH} 10$ to improve the production of highquality tea products.

\section{Materials and Methods}

\section{Experimental design}

The experiment was conducted at the experimental field, Tea Research and Development Center, Northern Mountainous Agriculture and Forestry Science Institute, Phu Ho, Phu Tho, Vietnam from 2015 to 2017. Fiveyear-old plants of tea variety $\mathrm{PH} 10$ were used as experimental material. A two factorial experiment was designed by split plot design with three replications. The main plot treatments were three fertilizer doses of $\mathrm{N}$ for one metric ton of fresh shoot products, D1 (30 kg N ha'), D2 (40 $\left.\mathrm{kg} \mathrm{N} \mathrm{ha}^{-1}\right)$, and D3 (50 kg N ha-1). The subplot treatments were two NPK ratios, R1 (3:1:1) and R2 (3:1:2). The sub-plot area was $100 \mathrm{~m}^{2}$.

\section{Crop management}

During the experiment, composted manure was applied twice with 30 tons each time in January 2015 and 2017. Mineral fertilizers and fermented soybean were applied annually as shown in Table 1. Other crop management was done following the cultivation manual for tea production (TCN 446-2001).

\section{Data collection}

The growth parameters including plant height $(\mathrm{cm})$, shape wide $(\mathrm{cm})$, shape thickness $(\mathrm{cm})$, and plant diameter $(\mathrm{cm})$ were collected once per year in November (before pruning). Plant height was measured from above ground to canopy surface. Canopy width was measured at the largest position of the canopy surface. Canopy height was measured from the last 
Table 1. Mineral fertilizer practices

\begin{tabular}{|c|c|c|c|}
\hline Mineral & Type of fertilizer & Time & Amount \\
\hline \multirow{4}{*}{ Nitrogen } & \multirow{4}{*}{$\mathrm{CO}\left(\mathrm{NH}_{2}\right)_{2}$} & March & $30 \%$ \\
\hline & & May & $20 \%$ \\
\hline & & July & $30 \%$ \\
\hline & & September & $20 \%$ \\
\hline Phosphorus & $3 \mathrm{Ca}\left(\mathrm{H}_{2} \mathrm{PO}_{4}\right)_{2} \cdot \mathrm{H}_{2} \mathrm{O}+7 \mathrm{CaSO}_{4}$ & January & $100 \%$ \\
\hline \multirow{2}{*}{ Potassium } & \multirow{2}{*}{$\mathrm{KCl}$} & February & $60 \%$ \\
\hline & & April & $40 \%$ \\
\hline \multirow{2}{*}{ Magnesium } & \multirow{2}{*}{$\mathrm{MgSO}_{4,}, 75 \mathrm{~kg} \mathrm{ha}^{-1}$} & February & $60 \%$ \\
\hline & & May & $40 \%$ \\
\hline \multirow{2}{*}{ Fermented soybean } & \multirow{2}{*}{$\begin{array}{l}\text { Ground soybean seed was soaked in freshwater and fermented } \\
\text { in 40-60 days, } 1 \text { ton ha } \text { h }^{-1}\end{array}$} & February & $50 \%$ \\
\hline & & August & $50 \%$ \\
\hline
\end{tabular}

pruning scar to the highest position of the canopy surface. Insect and disease infection rates were determined by QCVN 01-38:2010/BNNPTNT. Fresh shoot yield and yield components including shoot density, shoot weight, and shoot length were collected at harvesting. The harvestable shoot was determined by cutting it apart with a bud plus 3 young leaves and a stem from a fish leaf. Shoot density was determined by counting the number of shoots on the standard frame $(25 \times 25 \mathrm{~cm})$. Shoot weight was measured by the average of 100 shoot samples. Shoot length was measured by an average of 50 shoot samples. Shoot components were calculated by fresh weight of bud, $1^{\text {st }}$ leaf, $2^{\text {nd }}$ leaf, and $3^{\text {rd }}$ leaf, stem, and total shoot fresh weight. The fiber ratio was determined following the TCVN 1053:1986. Biochemical components were analyzed by corresponding methods for tannin, water extract, amino acid, and aromatic compound as detail in Hoang Le Thu et al. (2013). Sensory analysis of made Sencha and Oolong tea products were assessed following the standard evaluation by TCVN 3218-2012 and TCVN 1273:2019, respectively.

The economic efficiency from selling raw tea products of each fertilizer treatment was evaluated as follows: Profit (million VND ha ${ }^{-1}$ ) $=$ total revenue - total cost. The percentage of profit was calculated by the ratio of profit and total cost.

\section{Data analysis}

The data were subjected to analysis of variance according to Splitplot design using CROPSTAT 7.2 software. The least significant difference (LSD) test was used to compare the means among the treatments.

\section{Results}

\section{Effect of doses and ratios of mineral fertilizer on growth of PH10 tea variety}

The results in Table 2 showed that fertilizer ratios had significant effects on growth parameters, except for plant diameter. In R1 treatment, plant height was higher but canopy width and height were lower than those in R2 treatment. There were upward trends in response of tea plants to increasing fertilizer doses for all growth parameters. However, the difference was not significant between higher doses (D2 and D3) for plant height, canopy height, and plant diameter. Among combined treatments, the highest values belonged to D2R1, D3R1, and D3R2 for plant height; D2R2, D3R1, D3R2 for canopy width; and D2R1, D2R2, and D3R2 for canopy height. The differences among treatments for plant diameter were not significant.

\section{Effect of fertilizer doses and ratios on yield components of PH10 tea variety}

In R2 treatment, shoot density, shoot length, and shoot fresh yield were higher than those in 
Effects of mineral fertilizer doses and ratios on tea yield and quality

Table 2. Effect of fertilizer doses and ratios on the growth of $\mathrm{PH} 10$ tea variety

\begin{tabular}{|c|c|c|c|c|c|}
\hline Doses & Ratios & $\begin{array}{l}\text { Plant height } \\
\quad(\mathrm{cm})\end{array}$ & $\begin{array}{l}\text { Canopy width } \\
\text { (cm) }\end{array}$ & $\begin{array}{c}\text { Canopy height } \\
\text { (cm) }\end{array}$ & $\begin{array}{l}\text { Plant diameter } \\
\text { (cm) }\end{array}$ \\
\hline \multirow{2}{*}{ D1 } & $\mathrm{R} 1$ & $78.5^{\mathrm{c}}$ & $138.2^{\mathrm{e}}$ & $14.6^{\mathrm{d}}$ & $3.57^{\mathrm{a}}$ \\
\hline & $\mathrm{R} 2$ & $78.6^{c}$ & $140.2^{d}$ & $15.4^{\mathrm{c}}$ & $3.53^{\mathrm{a}}$ \\
\hline \multirow{2}{*}{ D2 } & $\mathrm{R} 1$ & $79.8^{a}$ & $143.7^{c}$ & $16.4^{\mathrm{a}}$ & $3.66^{a}$ \\
\hline & $\mathrm{R} 2$ & $79.2^{\mathrm{b}}$ & $146.8^{b}$ & $16.8^{\mathrm{a}}$ & $3.51^{\mathrm{a}}$ \\
\hline \multirow{2}{*}{ D3 } & $\mathrm{R} 1$ & $80.4^{\mathrm{a}}$ & $147.3^{\mathrm{ab}}$ & $15.9^{b}$ & $3.74^{\mathrm{a}}$ \\
\hline & $\mathrm{R} 2$ & $79.9^{a}$ & $148.5^{\mathrm{a}}$ & $16.3^{\mathrm{ab}}$ & $3.59^{a}$ \\
\hline \multicolumn{6}{|c|}{ Fertilizer doses } \\
\hline D1 & & $78.5^{\mathrm{b}}$ & $139.2^{c}$ & $15.0^{\mathrm{b}}$ & $3.55^{\mathrm{b}}$ \\
\hline D2 & & $79.5^{a}$ & $145.2^{b}$ & $16.6^{\mathrm{a}}$ & $3.59^{\mathrm{ab}}$ \\
\hline D3 & & $80.2^{\mathrm{a}}$ & $147.9^{\mathrm{a}}$ & $16.1^{\mathrm{a}}$ & $3.67^{a}$ \\
\hline \multicolumn{6}{|c|}{ Fertilizer ratios } \\
\hline $\mathrm{R} 1$ & & $79.6^{a}$ & $143.0^{\mathrm{b}}$ & $15.6^{b}$ & $3.66^{\mathrm{a}}$ \\
\hline R2 & & $79.2^{\mathrm{b}}$ & $145.2^{\mathrm{a}}$ & $16.2^{\mathrm{a}}$ & $3.54^{\mathrm{a}}$ \\
\hline
\end{tabular}

Note: Different superscripts in the same column show significance between treatments at $P<0.05$ by LSD.

R1 treatment. However, the differences between fertilizer ratios were not significant for yield and yield components. Increasing fertilizer dose supported better yield and yield components, but the significances were only found among higher dose treatments (D2 and D3) with D1 treatment for shoot density and shoot fresh yield. Among combined treatments, shoot density ranged from 279.3 to 340.0 shoot $\mathrm{m}^{-2}$, treatment D1R1 had the lowest shoot density, significantly lower than other treatments, except for D1R2 treatment. D1R1 also had the lowest shoot length which lower than D2R2 and D3R1 treatment, and shoot yield which lower than all other treatments (Table 3).

\section{Effect of fertilizer doses and ratios on pest infection of PH10 tea variety}

The infestation rates of green leafhopper, red spider mite, and yellow tea thrip were significantly higher in R2 treatment than those in $\mathrm{R} 1$ treatment. Increasing fertilizer doses also led to an increase in pest infestation rates. However, significant differences were only found among fertilizer doses for infestation rates of green leafhopper and red spider mite. Among combined treatments, infestation rates of all pests were highest in the combined treatment of D3 with R2 and R1 (Table 4).

\section{Effect of fertilizer doses and ratios on economic efficiency of raw tea products}

D2R2 and D3R1 brought about the highest profits (95.2 and 94.5 million VND ha ${ }^{-1}$, respectively). D2R2 also had the highest percentage of profit (80.2\%). The lowest economic efficiency came from fertilizer application of D1R1 with only 69.8 million VND $\mathrm{ha}^{-1}$ for profit and $64.6 \%$ for the percentage of profit (Table 5).

\section{Effect of fertilizer doses and ratios on shoot components of PH10 tea variety}

There were insignificant effects of fertilizer doses as well as ratios on shoot components of PH10 tea variety. The differences among combined treatments were not significant for almost all parameters except for the ratio of stem between D3R2 with other treatments, and the fiber ratio between D3R1 with D1R2 and D2R1 treatments (Table 6). 
Table 3. Effect of fertilizer doses and ratios on yield and yield components of $\mathrm{PH} 10$ tea variety

\begin{tabular}{|c|c|c|c|c|c|}
\hline Doses & Ratios & $\begin{array}{l}\text { Shoot density } \\
\left(\text { shoot } \mathrm{m}^{-2}\right)\end{array}$ & $\begin{array}{c}\text { Shoot weight } \\
\text { (g) }\end{array}$ & $\begin{array}{l}\text { Shoot length } \\
(\mathrm{cm})\end{array}$ & $\begin{array}{l}\text { Shoot yield } \\
\text { (tons ha-1) }\end{array}$ \\
\hline \multirow{2}{*}{ D1 } & $\mathrm{R} 1$ & $279.3^{b}$ & $1.03^{a}$ & $6.11^{\mathrm{b}}$ & $8.90^{c}$ \\
\hline & $\mathrm{R} 2$ & $309.4^{\mathrm{ab}}$ & $1.00^{\mathrm{a}}$ & $6.79^{\mathrm{ab}}$ & $9.78^{b}$ \\
\hline \multirow{2}{*}{ D2 } & $\mathrm{R} 1$ & $315.2^{\mathrm{a}}$ & $1.08^{\mathrm{a}}$ & $7.11^{\mathrm{ab}}$ & $10.13^{b}$ \\
\hline & $\mathrm{R} 2$ & $338.1^{\mathrm{a}}$ & $1.09^{a}$ & $7.18^{a}$ & $10.70^{\mathrm{ab}}$ \\
\hline \multirow{2}{*}{ D3 } & $\mathrm{R} 1$ & $340.0^{\mathrm{a}}$ & $1.16^{\mathrm{a}}$ & $7.48^{a}$ & $10.88^{a}$ \\
\hline & $\mathrm{R} 2$ & $330.5^{\mathrm{a}}$ & $1.10^{\mathrm{a}}$ & $7.15^{\mathrm{ab}}$ & $10.42^{\mathrm{ab}}$ \\
\hline \multicolumn{6}{|c|}{ Fertilizer doses } \\
\hline D1 & & $294.4^{b}$ & $1.02^{\mathrm{a}}$ & $6.45^{\mathrm{a}}$ & $9.34^{\mathrm{b}}$ \\
\hline D2 & & $326.7^{\mathrm{a}}$ & $1.09^{a}$ & $7.15^{\mathrm{a}}$ & $10.42^{\mathrm{a}}$ \\
\hline D3 & & $335.2^{\mathrm{a}}$ & $1.13^{a}$ & $7.32^{\mathrm{a}}$ & $10.65^{a}$ \\
\hline \multicolumn{6}{|c|}{ Fertilizer ratios } \\
\hline R1 & & $311.5^{\mathrm{a}}$ & $1.09^{a}$ & $6.90^{\mathrm{a}}$ & $9.97^{\mathrm{a}}$ \\
\hline $\mathrm{R} 2$ & & $326.0^{\mathrm{a}}$ & $1.06^{a}$ & $7.04^{\mathrm{a}}$ & $10.30^{\mathrm{a}}$ \\
\hline
\end{tabular}

Note: Different superscripts in the same column show significance between treatments at $P<0.05$ by LSD.

Table 4. Effect of fertilizer doses and ratios on pest infection of $\mathrm{PH} 10$ tea variety

\begin{tabular}{|c|c|c|c|c|}
\hline Doses & Ratios & No. GLH tray ${ }^{-1}$ & No. RSM leaf ${ }^{-1}$ & No. YTT shoot ${ }^{-1}$ \\
\hline \multirow{2}{*}{ D1 } & $\mathrm{R} 1$ & $3.3^{c}$ & $2.3^{\mathrm{c}}$ & $2.9^{c}$ \\
\hline & $\mathrm{R} 2$ & $3.5^{\mathrm{c}}$ & $2.1^{\mathrm{c}}$ & $2.8^{\mathrm{c}}$ \\
\hline \multirow{2}{*}{ D2 } & $\mathrm{R} 1$ & $4.5^{\mathrm{b}}$ & $2.2^{\mathrm{c}}$ & $2.9^{c}$ \\
\hline & $\mathrm{R} 2$ & $3.7^{c}$ & $2.1^{c}$ & $2.9^{c}$ \\
\hline \multirow{2}{*}{ D3 } & $\mathrm{R} 1$ & $4.8^{b}$ & $4.0^{b}$ & $3.8^{b}$ \\
\hline & $\mathrm{R} 2$ & $6.4^{\mathrm{a}}$ & $4.8^{\mathrm{a}}$ & $4.6^{\mathrm{a}}$ \\
\hline \multicolumn{5}{|c|}{ Fertilizer doses } \\
\hline D1 & & $3.4^{c}$ & $2.2^{b}$ & $2.8^{\mathrm{a}}$ \\
\hline D2 & & $4.1^{\mathrm{b}}$ & $2.2^{b}$ & $2.9^{\mathrm{a}}$ \\
\hline D3 & & $5.6^{a}$ & $4.4^{\mathrm{a}}$ & $4.2^{\mathrm{a}}$ \\
\hline \multicolumn{5}{|c|}{ Fertilizer ratios } \\
\hline R1 & & $4.2^{b}$ & $2.8^{b}$ & $3.2^{b}$ \\
\hline $\mathrm{R} 2$ & & $4.5^{\mathrm{a}}$ & $3.0^{\mathrm{a}}$ & $3.5^{\mathrm{a}}$ \\
\hline
\end{tabular}

Note: No. Number; GLH - Green leafhopper; RSM - Red spider mite; YTT - Yellow tea thrip. Different superscripts in the same column show significance between treatments at $P<0.05$ by $L S D$.

Effect of fertilizer doses and ratios on biochemical components of PH10 tea variety

Biochemical components in tea leaves of PH10 variety were not significantly different between fertilizer ratios, except for carbohydrates with higher value in R2 treatment compared to that in $\mathrm{R} 1$ treatment. The differences among biochemical components at fertilizer doses were found in tannin, water extract, and aromatic compound contents. Tannin content was lowest at D2 treatment, whereas water extract and aromatic compound 
contents were lowest at D1 treatment. At D2, aromatic compound content was significantly higher than those at other treatments. The highest tannin contents were found in D1R1 and D3R2 treatments. The water extract was highest in D3R1 treatment which was significantly higher than that in D1R1 and D1R2 treatment. Amino acid content ranged from 1.98 to $2.49 \%$, D1R1 had the lowest value but just significantly lower than D2R2 and D3R1. Carbohydrate and aromatic compound contents ranged from 2.19 to $3.08 \%$ and from 49.03 to $51.06 \%$, respectively, with the highest values in D2R2 treatment (Table 7).

Table 5. Effect of fertilizer doses and ratios on the economic efficiency of raw tea product of PH10 tea variety

\begin{tabular}{|c|c|c|c|c|c|}
\hline Doses & Ratios & $\begin{array}{c}\text { Total cost } \\
\left(\text { mil. VND ha }^{-1}\right)\end{array}$ & $\begin{array}{l}\text { Total revenue } \\
\left(\text { mil. VND ha }^{-1}\right)\end{array}$ & $\begin{array}{c}\text { Profit } \\
\left(\text { mil. VND ha }{ }^{-1}\right)\end{array}$ & $\begin{array}{l}\text { Percentage of profit } \\
\qquad(\%)\end{array}$ \\
\hline \multirow{2}{*}{ D1 } & $\mathrm{R} 1$ & 108.2 & 178.0 & 69.8 & 64.6 \\
\hline & $\mathrm{R} 2$ & 113.3 & 195.6 & 82.3 & 72.7 \\
\hline \multirow{2}{*}{ D2 } & $\mathrm{R} 1$ & 114.8 & 202.6 & 87.8 & 76.6 \\
\hline & $\mathrm{R} 2$ & 118.8 & 214.0 & 95.2 & 80.2 \\
\hline \multirow{2}{*}{ D3 } & $\mathrm{R} 1$ & 123.1 & 217.6 & 94.5 & 76.8 \\
\hline & $\mathrm{R} 2$ & 125.0 & 208.4 & 83.4 & 66.8 \\
\hline
\end{tabular}

Table 6. Effect of fertilizer doses and ratios on shoot mechanical components of PH10 tea variety

\begin{tabular}{|c|c|c|c|c|c|c|c|}
\hline \multirow{2}{*}{ Doses } & \multirow{2}{*}{ Ratios } & \multicolumn{5}{|c|}{ Weight ratio of tea shoot components (\%) } & \multirow{2}{*}{$\begin{array}{c}\text { Fiber ratio } \\
(\%)\end{array}$} \\
\hline & & Bud & $1^{\text {st }}$ leaf & $2^{\text {nd }}$ leaf & $3^{\text {rd }}$ leaf & Stem & \\
\hline \multirow{2}{*}{ D1 } & $\mathrm{R} 1$ & $6.3^{\mathrm{a}}$ & $10.2^{\mathrm{a}}$ & $20.0^{\mathrm{a}}$ & $32.5^{\mathrm{a}}$ & $31.0^{\mathrm{a}}$ & $12.1^{\mathrm{ab}}$ \\
\hline & $\mathrm{R} 2$ & $6.3^{\mathrm{a}}$ & $10.7^{\mathrm{a}}$ & $20.3^{a}$ & $32.4^{\mathrm{a}}$ & $30.4^{\mathrm{a}}$ & $13.4^{\mathrm{a}}$ \\
\hline \multirow{2}{*}{ D2 } & $\mathrm{R} 1$ & $6.4^{\mathrm{a}}$ & $10.6^{\mathrm{a}}$ & $20.6^{a}$ & $32.7^{a}$ & $29.9^{a}$ & $12.7^{\mathrm{a}}$ \\
\hline & $\mathrm{R} 2$ & $6.5^{\mathrm{a}}$ & $10.9^{\mathrm{a}}$ & $20.7^{a}$ & $33.5^{\mathrm{a}}$ & $28.5^{\mathrm{b}}$ & $12.4^{\mathrm{ab}}$ \\
\hline \multirow{2}{*}{ D3 } & $\mathrm{R} 1$ & $6.5^{\mathrm{a}}$ & $10.4^{\mathrm{a}}$ & $19.9^{\mathrm{a}}$ & $32.4^{\mathrm{a}}$ & $30.9^{a}$ & $10.7^{\mathrm{b}}$ \\
\hline & $\mathrm{R} 2$ & $6.4^{\mathrm{a}}$ & $10.6^{a}$ & $19.8^{a}$ & $32.1^{\mathrm{a}}$ & $31.1^{\mathrm{a}}$ & $12.5^{\mathrm{ab}}$ \\
\hline \multicolumn{8}{|c|}{ Fertilizer doses } \\
\hline D1 & & $6.3^{\mathrm{a}}$ & $10.4^{\mathrm{a}}$ & $20.1^{a}$ & $32.5^{\mathrm{a}}$ & $30.7^{a}$ & $12.8^{\mathrm{a}}$ \\
\hline D2 & & $6.4^{\mathrm{a}}$ & $10.7^{a}$ & $20.6^{a}$ & $33.1^{\mathrm{a}}$ & $29.2^{\mathrm{a}}$ & $12.5^{a}$ \\
\hline D3 & & $6.5^{\mathrm{a}}$ & $10.5^{a}$ & $19.8^{a}$ & $32.2^{\mathrm{a}}$ & $31.0^{\mathrm{a}}$ & $11.6^{a}$ \\
\hline \multicolumn{8}{|c|}{ Fertilizer ratios } \\
\hline R1 & & $6.4^{\mathrm{a}}$ & $10.4^{\mathrm{a}}$ & $20.1^{a}$ & $32.5^{\mathrm{a}}$ & $30.6^{a}$ & $11.8^{\mathrm{a}}$ \\
\hline $\mathrm{R} 2$ & & $6.4^{\mathrm{a}}$ & $10.7^{a}$ & $20.2^{\mathrm{a}}$ & $32.7^{a}$ & $30.0^{a}$ & $12.7^{a}$ \\
\hline
\end{tabular}

Note: Different superscripts in the same column show significance between treatments at $P<0.05$ by $L S D$.

Effect of fertilizer doses and ratios on sensory quality of Oolong and Sencha tea products

The effects of fertilizer doses and ratios on sensory quality parameters were shown in Table 8. The result pointed out that the scores of the shape of dry tea leaves and color water of made tea were not different among fertilizer doses and between two fertilizer ratios. Similarly, scores of flavor were not different among fertilizer doses, but different between fertilizer ratios with higher value belonging to made tea product in $\mathrm{R} 2$ 
treatment. In R2 treatment, made tea products also had a higher taste and overall scores compared to those in R1 treatment. Among fertilizer doses treatment, D1 had the lowest score for the taste of made tea, D2 had the highest mark for the overall score. The differences were also not significant among combined treatments for shape and color scores. D2R2 treatment showed the highest scores for flavor and taste. It also had the highest score overall with a score of 17.08, meanwhile, D1R1 had the lowest score (15.96).

Table 7. Effect of fertilizer doses and ratios on biochemical components of PH10 tea variety

\begin{tabular}{|c|c|c|c|c|c|c|}
\hline Doses & Ratios & $\begin{array}{c}\text { Tannin } \\
(\%)\end{array}$ & Water extract (\%) & $\begin{array}{c}\text { Amino acid } \\
(\%)\end{array}$ & $\begin{array}{c}\text { Carbohydrate } \\
(\%)\end{array}$ & $\begin{array}{c}\text { Aromatic compound } \\
(\%)\end{array}$ \\
\hline \multirow{2}{*}{ D1 } & $\mathrm{R} 1$ & $26.47^{a}$ & $41.72^{\mathrm{bc}}$ & $1.98^{\mathrm{b}}$ & $2.19^{c}$ & $49.03^{c}$ \\
\hline & $\mathrm{R} 2$ & $25.48^{\mathrm{bc}}$ & $41.55^{c}$ & $2.22^{\mathrm{ab}}$ & $2.37^{\mathrm{bc}}$ & $49.66^{\mathrm{bc}}$ \\
\hline \multirow{2}{*}{ D2 } & $\mathrm{R} 1$ & $25.52^{\mathrm{b}}$ & $42.21^{a b c}$ & $2.36^{\mathrm{ab}}$ & $2.38^{\mathrm{bc}}$ & $49.80^{\mathrm{bc}}$ \\
\hline & $\mathrm{R} 2$ & $24.78^{c}$ & $42.19^{a b c}$ & $2.49^{a}$ & $3.08^{a}$ & $51.06^{\mathrm{a}}$ \\
\hline \multirow{2}{*}{ D3 } & $\mathrm{R} 1$ & $25.5^{\mathrm{bc}}$ & $42.55^{\mathrm{a}}$ & $2.43^{a}$ & $2.36^{\mathrm{bc}}$ & $50.05^{b}$ \\
\hline & $\mathrm{R} 2$ & $26.38^{a}$ & $42.33^{a b}$ & $2.32^{\mathrm{ab}}$ & $2.44^{b}$ & $49.83^{b c}$ \\
\hline \multicolumn{7}{|c|}{ Fertilizer doses } \\
\hline D1 & & $25.98^{\mathrm{a}}$ & $41.64^{b}$ & $2.10^{a}$ & $2.28^{a}$ & $49.35^{c}$ \\
\hline D2 & & $25.15^{\mathrm{b}}$ & $42.20^{\mathrm{a}}$ & $2.43^{a}$ & $2.73^{a}$ & $50.43^{\mathrm{a}}$ \\
\hline D3 & & $25.94^{\mathrm{a}}$ & $42.44^{\mathrm{a}}$ & $2.38^{a}$ & $2.40^{\mathrm{a}}$ & $49.94^{b}$ \\
\hline \multicolumn{7}{|c|}{ Fertilizer ratios } \\
\hline R1 & & $25.83^{\mathrm{a}}$ & $42.16^{a}$ & $2.26^{a}$ & $2.31^{\mathrm{b}}$ & $49.63^{a}$ \\
\hline $\mathrm{R} 2$ & & $25.55^{\mathrm{a}}$ & $42.02^{\mathrm{a}}$ & $2.34^{a}$ & $2.63^{a}$ & $50.18^{a}$ \\
\hline
\end{tabular}

Note: Different superscripts in the same column show significance between treatments at $P<0.05$ by LSD.

Table 8. Effect of fertilizer doses and ratios on sensory quality of Oolong and Sencha teas

\begin{tabular}{|c|c|c|c|c|c|c|}
\hline Doses & Ratios & Shape & Color & Flavor & Taste & Overall \\
\hline \multirow{2}{*}{ D1 } & $\mathrm{R} 1$ & $4.10^{a}$ & $4.07^{a}$ & $3.97^{c}$ & $3.83^{c}$ & $15.96^{c}$ \\
\hline & $\mathrm{R} 2$ & $4.03^{a}$ & $4.03^{a}$ & $4.13^{\mathrm{abc}}$ & $4.13^{\mathrm{ab}}$ & $16.38^{b}$ \\
\hline \multirow{2}{*}{ D2 } & $\mathrm{R} 1$ & $4.23^{a}$ & $4.20^{\mathrm{a}}$ & $4.03^{b c}$ & $4.03^{b c}$ & $16.43^{b}$ \\
\hline & $\mathrm{R} 2$ & $4.07^{a}$ & $4.10^{\mathrm{a}}$ & $4.47^{a}$ & $4.33^{a}$ & $17.08^{a}$ \\
\hline \multirow{2}{*}{ D3 } & $\mathrm{R} 1$ & $4.10^{a}$ & $4.20^{\mathrm{a}}$ & $4.00^{\mathrm{abc}}$ & $4.03^{b c}$ & $16.27^{b}$ \\
\hline & $\mathrm{R} 2$ & $3.97^{a}$ & $3.90^{a}$ & $4.23^{\mathrm{abc}}$ & $4.23^{\mathrm{ab}}$ & $16.47^{b}$ \\
\hline \multicolumn{7}{|c|}{ Fertilizer doses } \\
\hline D1 & & $4.07^{a}$ & $4.05^{a}$ & $4.05^{\mathrm{a}}$ & $3.98^{\mathrm{b}}$ & $16.17^{\mathrm{b}}$ \\
\hline D2 & & $4.15^{a}$ & $4.15^{a}$ & $4.25^{\mathrm{a}}$ & $4.18^{a}$ & $16.76^{a}$ \\
\hline D3 & & $4.04^{a}$ & $4.05^{a}$ & $4.12^{\mathrm{a}}$ & $4.13^{a}$ & $16.37^{\mathrm{b}}$ \\
\hline \multicolumn{7}{|c|}{ Fertilizer doses } \\
\hline R1 & & $4.14^{a}$ & $4.16^{a}$ & $4.00^{b}$ & $3.96^{b}$ & $16.22^{\mathrm{b}}$ \\
\hline $\mathrm{R} 2$ & & $4.02^{\mathrm{a}}$ & $4.01^{a}$ & $4.28^{\mathrm{a}}$ & $4.23^{\mathrm{a}}$ & $16.64^{\mathrm{a}}$ \\
\hline
\end{tabular}

Note: Different superscripts in the same column show significance between treatments at $P<0.05$ by LSD. 


\section{Discussion}

\section{Effects of fertilizer doses and ratios on tea growth and yield}

Our findings in this experiment showed that increasing doses of fertilizer induced the upward trend of growth and yield parameters of the PH10 tea variety. However, the increases in these parameters were not significant when fertilizer doses increased from 40 to $50 \mathrm{~kg} \mathrm{~N}$ ton $^{-1}$. The ratio of NPK application had no significant effects on shoot yield and yield component, but significant on the growth of tea (except for plant diameter). At NPK ratio of 3:1:2, the plant height of the tea plant was lower, but leaf canopy parameters were higher than those at the ratio of $3: 1: 1$.

In Pakistan, Zaman et al. (2011) recorded that shoot length and fresh leaves yield was highest at the highest level when $\mathrm{N}$ was applied from 0 to $375 \mathrm{~kg} \mathrm{~N} \mathrm{ha}^{-1}$. Following Zaman et al. (2011) that the positive trend of increasing yield when supplying $\mathrm{N}$ up to $200 \mathrm{~kg} \mathrm{~N} \mathrm{ha}^{-1}$ in Tanzania (Anon, 2006), and $300 \mathrm{~kg} \mathrm{~N}$ ha $^{-1}$ (Rikhter \& Lyashko, 1979). In India, Gogoi et al. (1994) stated that yield benefits could be gained when $\mathrm{P}$ was applied up to $50 \mathrm{~kg} \mathrm{P}_{2} \mathrm{O}_{5} \mathrm{ha}^{-1}$. Similarly, Barbora (1991) reported that yield response to potash was quadratically reaching a peak at $170 \mathrm{~kg} \mathrm{~K}_{2} \mathrm{O} \mathrm{ha}^{-1}$ Meanwhile, in Pakistan, Islam et al. (2019) showed that application of $\mathrm{P}$ from 0 to $225 \mathrm{~kg} \mathrm{P}_{2} \mathrm{O}_{5} \mathrm{ha}^{-1}$ significantly enhanced plant height, number of leaves, leaf length, number of branches and fresh leaf yield. No improvement of yield by $\mathrm{K}$ application was found in Kenya (Willson, 1975) or Iran (Sedaghathoor et al., 2009). However, the available $\mathrm{K}$ content of the topsoil is found to be linearly correlated with tea yield (Singh \& Pathak, 2018). A foliar K application could escalate crop yield in tea (Barman et al., 2003). A better yield response to $\mathrm{N}$ is obtained when there is an adequate supply of $\mathrm{P}$ and $\mathrm{K}$ (Ellis, 1976; Owuor, 2001). Combination of each three levels of $\mathrm{N}\left(300,350\right.$ and $\left.400 \mathrm{~kg} \mathrm{~N} \mathrm{ha}^{-1}\right), \mathrm{P}(250$, 300 and $\left.350 \mathrm{~kg} \mathrm{P}_{2} \mathrm{O}_{5} \mathrm{ha}^{-1}\right)$, and $\mathrm{K}(150,200$ and $250 \mathrm{~kg} \mathrm{~K}_{2} \mathrm{O} \mathrm{ha}^{-1}$ ), Mudau et al. (2017) found no differences in tea growth for plant height, the number of branches, stem girth, fresh and dry root weight, and fresh and dry stem weight due to treatment combinations. However, treatment

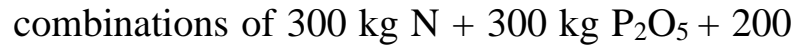
$\mathrm{kg} \mathrm{K}_{2} \mathrm{O}$ ha $^{-1}$ (3:3:2) supported the best growth with the highest value for fresh and dry shoot weight, number of leaves, and leaf area. In Kenya, yield response of tea is the same between NPK 20:10:10 and 25:5:5:5 (Owuor \& Othieno, 1996). Sitienei et al. (2013) also indicated no much difference between $\mathrm{N}-\mathrm{K}$ treatments, but the yield of made tea had a positive correlation with $\mathrm{N}$ application and a negative correlation with $\mathrm{K}$ application. In India, the recommended fertilizer ratios were an NK ratio of 1:0.45 to 1:1.66 for the southern part and NPK of 2:1:2 or 2:1:3 for the northern part (Singh \& Pathak, 2018). In Vietnam, with the total amount of $\mathrm{N}, \mathrm{P}_{2} \mathrm{O}_{5}$, and $\mathrm{K}_{2} \mathrm{O}$ of $300 \mathrm{~kg} \mathrm{ha}^{-1}$, NPK ratio of 3:2:1 was the most optimal dose for Phuc Van Tien and Shan Chat Tien varieties with the highest yield and yield components, following by $3: 2: 1,3: 1: 1$, and 2:1:1 (Nguyen Huu La, 2014).

\section{Effects of fertilizer doses and ratios on quality of raw material and made tea products}

Our results indicated that raw material components, leaf amino acid content, and sensory quality for shape and color of made tea were not affected by fertilizer dose and ratio. Differences between fertilizer ratios were found in carbohydrate content, sensory quality for taste, flavor, and overall score with higher values at NPK ratio of 3:1:2. The difference among fertilizer doses was found in contents of tannin and aromatic compound, and sensory quality of taste and overall, with the lowest value for tannin content and highest values for other parameters at the treatment of $40 \mathrm{~kg} \mathrm{~N} \mathrm{ton}{ }^{-1}$.

Sedaghathoor et al. (2009) reported that $\mathrm{N}$ application alone had significant effects on chemical components of tea leaf including tannin and water extract, whereas the combination of $\mathrm{N}$ and $\mathrm{K}$, and $\mathrm{K}$ application alone were significant on the caffeine percentage. Similarly, Takeo (1992) and Nishino (1999) found that yield and green tea quality seemed to be improved somewhat by higher application of $\mathrm{N}$. Nevertheless, some researchers found the decline 
in black tea quality with high rates of $\mathrm{N}$ application (Malenga, 1987; Owuor et al., 1994). Meawhile, Owuor et al. (1995) found that there is no quality benefit/loss from increased $\mathrm{N}$ rate. Ruan et al. (1999) found that increases in the contents of free amino acids, caffeine, polyphenols in tea leaves, and flavor compounds in brewed Oolong tea by K application. Singh \& Pathak (2018) reviewed that K offers abiotic and biotic stress toleration in tea plants and also improves biochemical parameters and organoleptic quality of tea. Lin et al. (2012) indicate that the sensory and biochemical qualities of green tea were lowered by $\mathrm{P}$ deficiency. The $\mathrm{P}$ deficient green tea displayed decreased concentrations of water extract, total polyphenols, flavonoids, total free amino acids, increased concentrations of water-soluble sugars, but unchanged concentrations of total catechins. Combinations of $\mathrm{P}$ and $\mathrm{K}$ and $\mathrm{N}$ were shown to be beneficial to enhance tea quality (Willson \& Choudhury, 1968). Mudau et al. (2017) reported that the treatment combination of $300 \mathrm{~kg} \mathrm{~N}+300$ $\mathrm{kg} \mathrm{P}_{2} \mathrm{O}_{5}+200 \mathrm{~kg} \mathrm{~K} \mathrm{~K}_{2} \mathrm{O}$ increased the concentration of total polyphenols, whereas other treatments did not consistently affect them. Owuor et al. (1987) reported that tea quality was similar to rates of $\mathrm{N}$ for NPK 20:10:10 and NPKS 25:5:5:5. Singh \& Pathak (2018) observed that a major increase in tea quality could be achieved when a balanced $\mathrm{NK}$ ratio (1:0.83) is the practice in the field. In Vietnam, Nguyen Huu La (2014) suggested 3:1:2 was the best NPK ratio for green tea production.

\section{Conclusions}

Increasing fertilizer doses from 30 up to 40 $\mathrm{kg} \mathrm{N}$ ton $^{-1}$ of fresh product remarkably improved growth, yield, and made tea quality of PH10 variety. Different fertilizer ratios resulted in variations in plant growth, the content of carbohydrate, sensory quality for taste and flavor as well as total sensory quality with higher values at NPK ratio of 3:1:2. Applying mineral fertilizer with $40 \mathrm{~kg} \mathrm{~N}$ per ton of fresh shoot products and NPK ratio of 3:1:2 brought about the highest tea yield and quality as well as economic profit.

\section{Acknowledgments}

This study was supported by grants from the Vietnamese Ministry of Agriculture and Rural Development (Grant-in-Aid for study on intensive cultivation to improve yield and quality of Kim Tuyen and PH10 tea varieties to meet export market of Japan and Republic of China).

\section{References}

Amali R. K. A., Abeyweera N. H. A. S., Gunaratne O. G. K. A. \& Kottawa-Arachchi J. D. (2019). Response of new tea (Camellia sinensis L.) accessions to different nitrogen rates in up country region of Sri Lanka. Proceedings of the $7^{\text {th }}$ Symposium on Plantation Crop Research, At Colombo.

Anon (2006). Responses of irrigated clonel tea to various rates of nitrogen fertilizer. Annual Report, 2005-06. Tea Research Institute, Tanzania: 30-36.

Barbora B.C. (1991). Fertilizer use in tea. Two and A Bud. 38: $1-2$.

Barman T. S., Saikia J. \& Baruah U. (2003). Foliar application of potash on starch reserve in tea. Two Bud. 50: 39-41.

Clowes M. S. J. (1986). New nutrition trial on selected clones in a season with good rainfall. Tea Research Foundation of Central Africa, Quart. Newlett. 83: 9-11.

Ellis R. T. (1976). The case for use of phosphate and potash. Tea Research Foundation of Central Africa, Quart. Newslett. 42: 3-6.

FAOSTAT (2018). Food and Agriculture Data. Retrieved from http://www.fao.org/faostat/en on November 20, 2019.

Gogoi A. K., Chaudhary D., Gogoi M. N. \& Charkravartee J. (1994). Effect of phosphorus on nitrogen metabolism in tea plant. Two and A Bud. 41(1): 42-47.

Hajiboland R. (2017). Environmental and nutritional requirements for tea cultivation. Folia Horticulturae. 29(2): 199-220.

Hoang Le Thu, Nguyen Dinh Vinh \& Do Van Ngoc (2013). Effect of fertilizer and pruning on the yield and quality of raw materials for processing Oolong tea in Phu Tho. Journal of Science and Development. 11(4): 492-500 (in Vietnamese).

Islam S., Hamid F. S., Zaman Q., Shah B. H., Ahmad F., Shad H. \& Aftab S. (2019). Effect of different levels of phosphorus on the growth and yield of tea. Open Academic Journal of Advance Science and Technology. 3(1): 11-16.

Lin Z. H., Qi Y. P., Chen R. B., Zhang F. Z. \& Chen L. S. (2012). Effects of phosphorus supply on the quality of green tea. Food Chemistry. 130: 908-914. 
Malenga N. E. A. (1987). The effect of different levels of nitrogen on yield, quality and value of made tea in Mulanje, Malawi. Quarterly Newsletter, Tea Research Foundation on Central Africa. 87: 7-11.

Mudau F. N., Soundy P. \& Toit E. S. (2017). Nitrogen, phosphorus, and potassium increases growth and total polyphenol concentrations of bus tea in a shaded nursery environment. HorTechnology. 17(1): 107-110.

Nishino T. (1999). Effects of nitrogen fertilizer application on the yield and quality of tea [Camellia sinensis], and measures to reduce the leaching of nitrogen. Retrieved from https://agris.fao.org/agrissearch/search.do?recordID=JP1999004248 on December 15, 2019.

Nguyen Huu La (2014). Results of field experiments of fertilizer management for some new tea varieties during year 2000-2012. Retrieved from http://iasvn.org/chuyen-muc/Ket-qua-nghien-cuubon-phan-cho-mot-so-giong-che-moi-giai-doan-20002012-4601.html on March 12, 2014 (in Vietnamese).

Owuor P. O., Othieno C. O., Horita H., Tsushida T. \& Murai T. (1987). Effects of nitrogenous fertilizers on the chemical composition of black tea. Agricultural and Biological Chemistry. 51: 2665-2670.

Owuor P. O., Obanda M. \& Othieno C. O. (1994). Effects of rates and ratios of nitrogenous and potash fertilizers on tea in the eastern highlands of Kenya: III. Quality and value. Tea. 15(1): 42-49.

Owuor P. O., Obanda M. \& Wanyoko J. K. (1995). Quality response of low yielding tea to rates and splitting nitrogen fertilizer application in the eastern and western Kenya highlands. Tea. 16: 124-128.

Owuor P. O. \& Othieno C. O. (1996). Optimising nitrogen fertilizer application rates to different tea cultivars. Tropical Science. 36: 211-223.

Owuor P. O. (2001). Effects of fertilizers on tea yields and quality. A review with special reference to Africa and Sri Lanka. International Journal of Tea Science. 1(1):1-11.

QCVN 01-38:2010/BNNPTNT. National technical regulation on surveillance method of plant pests. Ministry of Agriculture and Rural Development, dated December 10, 2010.

Qiu S. L., Wang L. M., Huang D. F., \& Lin X. J. (2014). Effects of fertilization regimes on tea yields, soil fertility, and soil microbial diversity. Chilean Journal of Agricultural Research. 74(3): 333-339.

Rikhter M. A. \& Lyashko M. U. (1979). The effect of high nitrogen rates on the yield and quality of irrigated tea. Subtropicheskie Kultury. 1: 36-43.

Ruan J., Wu X. \& Härdter R. (1999). Effects of potassium and magnesium nutrition on the quality components of different types of tea. Journal of the Science of Food and Agriculture. 79(1): 47-52.

Sedaghathoor S., Torkashvand A. M., Hashemabadi D. \& Kaviani B. (2009). Yield and quality response of tea plant to fertilizers. African Journal of Agricultural Research 4(6): 568-570.

Singh A. K. \& Pathak S. K. (2018). Potassium in tea (Camellia sinensis L. O Kuntze) cultivation from soil to cup quality - A review. Agricultural Reviews. 39(1): 40-47.

Sitienei K., Home P. G., Kamau D. M. \& Wanyoko J. K. (2013). Nitrogen and potassium dynamics in tea cultivation as influenced by fertilizer type and application rates. American Journal of Plant Sciences. 4: 59-65.

Takeo T. (1992). Green and semi-fermented teas. In tea: Willson K. C. \& Clifford M. N. (Eds.) Cultivation to consumption. London, Chapman and Hall: 413-457

Tang S., Liu Y., Zheng N., Li Y., Ma Q., Xiao H., Zhou X., Xu X., Jiang T., He P. \& Wu L. (2020). Temporal variation in nutrient requirements of tea (Camellia sinensis) in China based on QUEFTS analysis. Scientific Reports. 10: 1745.

TCVN 1053:1986. Tea leaf- Method for the determination of fiber of tea leaf. National Science and Technology Council, issued on April 10, 1986 (in Vietnamese).

TCVN 3218-2012. Tea- Sensory analysis by presenting mark. Ministry of Science and Technology, issued on January 1, 2012 (in Vietnamese).

TCVN 1273:2019. Oolong tea- Basic requirements. Ministry of Science and Technology, issued on December 31, 2019 (in Vietnamese).

TCN 446:2001. Technical procedure for tea production. Ministry of Agriculture and Rural Development, issued on March 7, 2001 (in Vietnamese).

Venkatesan S. \& Ganapathy M. N. K. (2004). Impact of nitrogen and potassium fertilizer application on quality of CTC teas. Food Chemistry. 84(3):325-328.

VITIC (2020). Tea export market 2019. Retrieved from http://vinanet.vn/thuong-mai-cha/thi-truong-xuatkhau-che-nam-2019-724458.html on May 12, 2020 (in Vietnamese).

Willson K. C. (1975). Studies on the mineral nutrition of tea. Potassium. Plant and Soil. 43: 279-293.

Willson K. C. \& Choudhury R. (1968). Fertilizers and tea quality. Two and A Bud. 15(3): 92-95.

Zaman Q., Sarwar S., Ahmad F. \& Hamid F. S. (2011). Effect of nitrogenous fertilizer on the growth and yield of tea (Camellia sinensis L.) pruned in curved vs flat shape. Journal of Agricultural Research. 49(4): 477-482. 